\title{
Psychological Training of the Development of Personality's Subjectivity at Adolescence
}

\section{Психологічний тренінг розвитку суб'єктності особистості в підлітковому віці}

\section{Nataliia Ternovyk}

Ph.D. in Psychology, Assistant Professor, International University of Economics and Humanities named after Stepan Demianchuk, Rivne (Ukraine)

ORCID ID: https://orcid.org/0000-0002-1425-2423

Researcher ID: AAH-8779-2020

E-mail: nato4ka66@ukr.net

\section{Наталія Терновик}

Кандидат психологічних наук, доцент, Міжнародний економіко-гуманітарний університет імені академіка Степана Дем'янчука, м. Рівне (Україна)

\section{Nataliia Slavina}

Ph.D. in Psychology, Assistant Professor, Kamianets-Podilskyi National Ivan Ohiienko University, Kamianets-Podilskyi (Ukraine)

ORCID ID: https://orcid.org/0000-0003-3381-1291

E-mail: Slavina_nat@ukr.net

\section{Наталія Славіна}

Кандидат психологічних наук, доцент, Кам'янець-Подільський національний університет імені Івана Огієнка, м. Кам'янець-Подільський (Україна)

The author's contribution: N. Ternovyk $-50 \%$, N. Slavina $-50 \%$.

Авторський внесок: Н. Терновик -50\%, Н. Славіна - 50\%.

Address for correspondence, e-mail: kpnu_lab_ps@ukr.net Copyright: (C) Ternovyk Nataliia, Slavina Nataliia

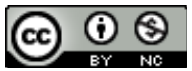
The article is licensed under CC BY-NC 4.0 International (https://creativecommons.org/licenses/by-nc/4.0/)

(C) Ternovyk Nataliia, Slavina Nataliia

DOI (article): https://doi.org/10.32626/2227-6246.2020-48.272-292 http://journals.uran.ua/index.php/2227-6246 


\section{ABSTRACT}

The purpose of our research is to develop a comprehensive training program for the development of the personality's subjectivity at school age.

Methods of the research. The following theoretical methods of the research were used to solve the tasks formulated in the article: the categorical method, the structural and functional methods, the methods of the analysis, systematization, modeling, generalization.

The results of the research. It is noted that the category of "a subject» as a qualitative characteristic of human activity determines the place and role of the person in the world, his / her abilities to provide the activity, which actualize the processes of self-determination and personal development. In Psychology a subject is understood as a person who is the source of purposeful (and thereforeconscious) activity, subordinated to the "image of the desired future», that is the goal of personal development.

The concept of "the subject of mental activity" is considered to be the key one for our research. It is stated that a person as a subject has a direct regulatory effect on his / her own psyche and through the mediation of the psyche he / she affects the surrounding world, and the mature subject is able to become aware of his / her personality. A mature subject of mental activity is an individual who is aware of himself / herself as a creator of his / her own psyche, whose development, protection, restoration and correction (if it is necessary) is consciously set for some purpose and have to be purposefully exercised. Therefore, the mature subject of mental activity will reach the level of the subject of mental activity; that is conscious regulation, as well as reflection being its constituent, which are the criterion that distinguish these two levels of subjectivity. It is emphasized that the individual can be the subject of mental activity if the object is his / her own psyche in its functioning and development. It is proved that the subject appears in a case of awareness of the object. It is emphasized that it is impossible to realize the object without reflection, therefore, there is no subject without reflection.

There were developed exercises of training program for the development of the personality's subjectivity at the adolescence.

Conclusions. It was proved that for a purposeful influence on the development of a teenager, his / her cognitive activity, teachers would clearly present for themselves the image of subjectivity, which was reflected in certain aspects of the activity, such as: conditioned mental image of gained experience, needs, attitudes, emotions, goals and motives, having been determined by

(C) Ternovyk Nataliia, Slavina Nataliia DOI (article): https://doi.org/10.32626/2227-6246.2020-48.272-292 
DOI: https://doi.org/10.32626/2227-6246.2020-48 2020. випУск 48

manageability and selectivity of pupils' activity. To become a subject involves the emergence of processes of the development and prioritization of goals, problems and choices regarding the solution and formulation of tasks and solutions. So, subjectivity is purely socio-cultural unit in nature, since the ultimate cause of individual's actions is always characterized in time, space, meaning, and among direct and indirect participants in the activity.

Key words: a subject, subjectivity, a subject of mental activity, cognitive activity, a subject of psychological activity, psychological training of the development of personality's subjectivity.

\section{Вступ}

Раціогуманізація навчально-виховного процесу сучасної школи перш за все орієнтована на збереження винятковості й неповторності особистості кожного учня. Адже діти - це майбутнє суспільства і держави. Тому необхідно звернути увагу на розвиток їх суб'єктності й тих важливих якостей, які відображають індивідуальність особистості. Найширша можливість утілення в життя індивідуальних якостей дитини з'являється у навчальній діяльності. Й не останне місце у ній посідає створення ефективних психологічних умов для розвитку учнів як суб’єктів пізнавальної діяльності.

Безперечним є факт, що однією з укорінених тенденцій у шкільному викладанні є те, що учня сприймають більш як об'єкт педагогічного впливу, ніж як суб'єкт навчання (Михальчук, 2008). Учитель та учень перебувають у ситуації загрози виникнення непорозумінь і конфліктів. Особливо це стосується школярів підліткового віку з притаманними їм більш високим рівнем розвитку самосвідомості, здатністю до самореалізації та прагненням до самоствердження.

Отже, становлення підлітка, формування його самостійності, розвиток особистості як суб’єкта пізнавальної діяльності, найповніша реалізація творчого потенціалу школяра залишаються найактуальнішими завданнями навчально-виховного процесу сучасної школи.

(C) Ternovyk Nataliia, Slavina Nataliia

DOI (article): https://doi.org/10.32626/2227-6246.2020-48.272-292 http://journals.uran.ua/index.php/2227-6246 
Слід наголосити на тому, що поряд із психологією особистості, психологією індивідуальності як традиційними напрямами вітчизняної психології, активно намагається утвердити себе психологія суб'єктності. Як відомо, однією з найбільш загальних норм є образ суб'єкта (Максименко, Ткач, Литвинчук \& Онуфрієва, 2019). Суб’єкт у цьому контексті розглядається як джерело свідомої активності людини. Образ суб'єкта здійснює регулюючу функцію в суспільстві й історично розвивається у процесі соціальної практики. Його основні риси засвоюються особою під час спілкування й особливо активно під час навчання.

Перш ніж проявити себе у соціальній взаємодії, людина намагається передбачити свої дії, відбудувати образ себе в певній ситуації. Таке усвідомлення себе як діяча, як джерела своєї активності спирається на загальноприйняті уявлення про суб’єкта. Вони є основою рефлексій індивіда, бачення ним свого «Я» з боку інших.

Проте, в психологічній літературі не всі питання залишаються до кінця розв'язаними. Зокрема, до сих пір немає створеної цілісної тренінгової програми розвитку суб’єктності особистості в шкільному віці. Це і стало метою нашого дослідження.

\section{Завдання статті}

1. Окреслити категорію «суб'єкт» як якісну характеристику активності людини.

2. Обгрунтувати поняття «суб'єкт психічної активності».

3. Розробити вправи для тренінгової програми розвитку суб’єктності особистості в підлітковому віці.

\section{Методи дослідження}

Для розв'язання поставлених у роботі завдань використовувалися такі теоретичні методи дослідження: категоріальний, структурно-функціональний, аналіз, систематизація, моделювання, узагальнення.

(C) Ternovyk Nataliia, Slavina Nataliia DOI (article): https://doi.org/10.32626/2227-6246.2020-48.272-292 


\section{Результати та дискусії}

Категорію «суб'єкт» як якісну характеристику активності людини визначає К. О. Абульханова-Славська та вказує, що це поняття обумовлює місце і роль людини у світі, здатність до діяльності, самодіяльності, самовизначення та розвитку (Абульханова-Славская, 1993: 109).

В. М. Титов під суб'єктом розуміє людину, яка є джерелом цілеспрямованої (а отже, свідомої) активності, підпорядкованої «образу потрібного майбутнього», тобто, - цілі (Титов, 1993: 143).

Досліджуючи генетичні аспекти суб'єктності, В. О. Татенко як ключове обирає поняття «суб'єкт психічної активності». Він зазначає, що людина в цій якості виявляє безпосередню регулятивну дію на власну психіку та посередництвом психіки впливає на оточуючий світ, а зрілий суб'єкт здатен до усвідомлення своєї суб'єктності. Зрілий суб'єкт психічної активності, на думку автора, є індивідом, який усвідомлює себе носієм і творцем власної психіки, розвиток якої, захист, відновлення та корекцію (у разі потреби) свідомо покладає собі за мету й цілеспрямовано здійснює (Татенко, 1993: 92-93). Справедливість наведеного визначення не викликає сумніву, якщо не заглиблюватися в онтогенез розвитку суб'єкта, запропонований автором. Із вищевикладеного стає зрозуміло, що зрілий суб'єкт психічної активності досягає рівня суб'єкта психічної діяльності; тобто, свідома регуляція, а також і рефлексія як її складова, є тим критерієм, який розрізняє ці два рівні суб'єктності (Harre, 1983). В. О. Татенко підкреслює, що суб’єктом психічної активності індивід може мислитися у тому випадку, якщо об'єктом для нього виступає його власна психіка в iii функціонуванні та розвитку (Татенко, 1993: 92-93). Тоді не зовсім зрозумілими є погляди автора щодо існування суб'єкта в пренатальному періоді. Адже сумнівно, що ненароджена людська істота здатна покладати власну психіку в якості об’єкта розвитку. А. В. Брушлинський зазначав, (C) Ternovyk Nataliia, Slavina Nataliia

DOI (article): https://doi.org/10.32626/2227-6246.2020-48.272-292 
що для новонародженого, який є початково активним уже в пренатальному періоді, ті чи інші компоненти оточуючої дійсності постають спочатку як подразники. Пізніше ті ж самі речі та явища усвідомлюються в якості об'єкта. Відтак, приходимо до висновку, що суб'єкт виникає тоді, коли відбувається усвідомлення об'єкта. Але усвідомити об'єкт без рефлексії неможливо. Отже, суб'єкт без рефлексії не існує (Брушлинский, 1994).

Визначивши зміст категорії суб'єктності, опишемо вправи з розробленої нами тренінгової програми «Розвиток суб'єктності особистості в підлітковому віці» .

\section{ЗАНЯТТЯ 1. ТЕМ А: “СВIT У МЕНI...» (14 годин)}

Мета: створення умов для кращого знайомства й визначення особливостей кожного учасника; створення сприятливого психологічного клімату.

Ведучий пропонує членам групи сісти в коло обличчям один до одного і розповісти про те, яку допомогу вони отримають від участі в тренінгу інформування.

Коли мова йде про самовизначення у вашому віці, то мають на увазі, звичайно, ваше майбутнє. I це, без сумніву правильно, хоча й однобічно. Насправді, мова повинна йти не тільки про майбутнє, але й про теперішнє.

Людина перш за все думає про своє теперішне і саме в теперішньому вона прагне (свідомо чи стихійно) знайти своє місце в навколишньому світі. Тому тільки пошук і знаходження свого місця в сьогоднішньому житті роблять реальним та обміркованим пошук свого майбутнього. Яке ж місце в оточуючому світі шукає кожен із вас? На це запитання неможливо відповісти одразу.

Юнаки та дівчата, змінюючись у процесі свого розвитку, змінюють і свої погляди на оточуючих і навколишній світ. Відчуваючи своє дорослішання, відкриваючи свій внутрішній світ, вони шукають «сценарій» своєї нової поведінки.

Особистість у підлітковому віці пізнає світ, пізнає себе, при цьому рано чи пізно вона стикається з низкою запитань.

(C) Ternovyk Nataliia, Slavina Nataliia DOI (article): https://doi.org/10.32626/2227-6246.2020-48.272-292 
Наприклад, із такими: "Хто я є в цьому світі?», «Яке моє місце в ньому?», «Як ставиться до мене світ?», «Як я сам ставлюся до світу?». Пошуки відповідей на ці й подібні їм запитання можна назвати сутністю самовизначення у світі.

У віці 11-14 років визначити своє місце у житті означає, в першу чергу, визначити ставлення до самого себе i до оточуючих людей. Тому участь у тренінгу, перш за все, допоможе кожному з вас усвідомити свої стосунки з оточуючим світом; розібратися у важливих для вас питаннях; зрозуміти себе та знайти способи особистісного розвитку; зняти внутрішні напруження, конфлікти, пізнати свої сильні та слабкі сторони. Тренінг допоможе сформувати вміння досконалішого психологічного аналізу особистості; краще розібратися в тому, що з вами відбувається, чому так, а не інакше, складається ваше життя; будувати самих себе та впливати на своє власне життя.

\section{Завдання 1. Гра «Ім'я».}

Мета: дізнатися і запам'ятати імена всіх учасників тренінгу; зняти можливі ускладнення при спілкуванні.

Кожен учасник по колу називає імена всіх, хто представився, останній називає своє ім'я.

\section{Завдання 2. Правила роботи у групі.}

Мета: встановлення принципів роботи у групі.

Пропонуємо для вільного обговорення правила роботи у групі.

1. Активність, відповідальність кожного за результати роботи групи.

2. Постійність роботи у групі. Кожен учасник групи зобов'язаний відвідувати заняття впродовж усього часу, без перерви.

3. Закритість групи. Усе, що відбувається у групі, не повинно виноситися за їі межі.

4. Відвертість і щирість. Усі члени групи повинні намагатися відкинути всі ролі й бути самими собою, спробувати говорити те, що вони думають, і виявляти те, що відчувають. (C) Ternovyk Nataliia, Slavina Nataliia

DOI (article): https://doi.org/10.32626/2227-6246.2020-48.272-292 
5. Правило «Стоп!». Той член групи, який не бажає відповідати на певне запитання, брати участь у якійсь грі, бути відвертим, має право сказати: «Стоп!» і виключити себе 3 участі у процедурі.

\section{Завдання 3. Знайомство.}

Meта: формування першого враження одне про одного; створення клімату психологічної безпеки; формування настановлення на саморозуміння.

Учасникам роздається по 10-15 аркушів, на кожному 3 яких вони мають написати по одній своїй особистісній якості, а потім самі ж учасники розташують аркуші за значущістю. При обговоренні слід звернути увагу на те, які характеристики свого «Я» переважають у кожного з учасників - позитивні чи негативні: що для кожного є найбільш значущим у своїй особистості, наскільки яскраво виявляються якості, що займають останне місце.

\section{Завдання 4. Розминка.}

Meтa: зняття напруженості, втоми, створення доброзичливої атмосфери.

Гра «Хащі». Один із членів групи намагається проникнути в центр тісного кола, утвореного учасниками групи.

Завдання 5. Рефлексія «тут і тепер».

Мета: вироблення навику рефлексії.

1. Дати поняття рефлексії та пояснити учасникам необхідність їі здійснення на початку і в кінці кожної зустрічі.

Інфорлування

Спостерігаючи за собою, своїми вчинками, думками, переживаннями, людина часто стикається з їх неоднозначністю, суперечливістю. Вона прагне зрозуміти, що в них істинне, а що ні. Цей пошук відбувається у процесі діалогу. Внутрішній діалог із самим собою або з іншою людиною дає можливість особистості стати на позицію дослідника стосовно самої себе. Це пов'язано з тим, що у процесі діалогу в людини розвивається рефлексія. Рефлексія (з лат. «refleхіо» - повернення назад) - процес пізнання людиною са-

(C) Ternovyk Nataliia, Slavina Nataliia DOI (article): https://doi.org/10.32626/2227-6246.2020-48.272-292 
DOI: https://doi.org/10.32626/2227-6246.2020-48 2020. випуск 48 мої себе, свого внутрішнього світу, аналіз власних думок i переживань, роздумів про саму себе, усвідомлення того, як сприймають і оцінюють ї̈ інші.

Рефлексія не тільки дає змогу пізнати себе, але й сприяє дорослішанню особистості. Пізнаючи себе, вона все більше звільняється від некритичного сприйняття впливу оточуючих. Чим сильніше розвинута рефлексія, тим більше хлопці та дівчата стають спроможними розв'язувати завдання, які перед ними виникають.

2. Запропонувати кожному учаснику висловити своє розуміння того, що відбувається у групі та з групою, описати свої почуття і переживання, думки, які виникають у процесі роботи.

3. Оцінити за десятибальною шкалою ступінь втоми, інтересу до роботи.

\section{Завдання на самопізнання.}

Mета: усвідомлення свого психологічного стану; вироблення навичок аналізу своєї особистості, поведінки.

Запропонувати учням почати вести вдома щоденник, у якому описувати все те, що з ними відбувається під час тренінгу. Аналізувати причини виникнення тих чи інших переживань, почуттів, реакцій на події у групі.

Завдання:

а) пригадайте сьогоднішню роботу в групі та завершіть такі фрази:

- Я зрозумів...;

- Мене здивувало...;

- Я відчув...;

- Думаю...;

- Сьогодні мене дратувало...;

- Мені дуже сподобалося...;

б) напишіть психологічний автопортрет. Спробуйте побачити себе збоку. Можна написати, які особисті якості у вас найяскравіші.

C Ternovyk Nataliia, Slavina Nataliia

DOI (article): https://doi.org/10.32626/2227-6246.2020-48.272-292 
ЗАНЯТТЯ 2. ТЕМА: «СВІТ НАВКОЛО МЕНЕ» (12 годин)

Mema: допомогти учасникам зафіксувати і на цій основі почати розвивати свої вміння бачити, відчувати, адекватно сприймати себе й інших людей.

\section{Завдання 1. Рефлексія.}

Мета: розвиток навичок рефлексї, самодіагностики своїх станів.

Ведучий пропонує всім сісти в коло і просить кожного учасника описати свій стан у цей момент, визначити причину наявного емоційного стану.

Дізнатися в учнів про виконання завдання на самопізнання (як упорались, які виникли труднощі, чому). Попросити одного з учасників прочитати фрагмент зі щоденника. Після цього всі учасники описують свої відчуття, що виникли під час прослуховування, і мають визначити почуття автора, які він переживав при написанні. Сам автор підтверджує або спростовує гіпотезу.

\section{Завдання 2. Фраза.}

Mета: допомогти учасникам усвідомити ступінь свого вміння визначати стан іншої людини за невербальними компонентами спілкування.

Ведучий пропонує 2-3 учасникам вийти за двері та подумати, яким чином кожен із них може зобразити за допомогою міміки, жестів, інтонації стан, у якому він знаходиться у цей період життя. Потім кожен із них виконує це завдання перед членами групи, а вони мають якомога точніше визначити цей стан у процесі загального обговорення.

\section{Завдання 3. Бачення інших.}

Mета: визначення вміння учасників бачити, адекватно сприймати інших людей.

Ведучий називає одного з учасників. Усі разом мають відтворити його поведінку, настрій, висловлювання, пози від самого початку заняття і до цього моменту.

(C) Ternovyk Nataliia, Slavina Nataliia DOI (article): https://doi.org/10.32626/2227-6246.2020-48.272-292 
Завдання 4. Розминка.

Мета: зняття напруження.

Гра «Стебельце на вітрі». Один із членів групи стає в центр кола і закриває очі. Усі інші стоять обличчям до кола, щільно один біля одного, i, витягнувши руки перед собою, починають розхитувати того, хто всередині кола.

Завдання на самопізнання.

Мета: формування вмінь аналізувати особистісні якості та поведінку інших людей.

Написати міні-твір «Яким я бачу кожного учасника тренінгу», використовуючи метод асоціацій.

\section{ЗАНЯТТЯ 3. ТЕМА: "Я ОЧИМА СВІТУ» (12 годин)}

Мета: надати можливість учасникам побачити себе очима інших людей; співвіднести оцінку та самооцінку членів групи; корекція сприйняття себе й інших.

Завдання 1. Аналіз асоціацій.

Mета: надати можливість кожному члену групи дізнатися, як його сприймають інші учасники; корекція власного сприйняття інших людей.

Зібрати у членів групи щоденники, попередивши, що імена авторів асоціацій називатися не будуть.

Запропонувати учасникам упродовж 1-2 хвилин уважно подивитися один на одного. Далі попросити всіх обрати зручну позу, заплющити очі й спробувати уявити того учасника, про якого йде мова (ведучий зачитує щоденники).

Після закінчення процедури учасники діляться своїми враженнями. Ведучий може дізнатися, кого з учасників було легко уявити, а кого складно, і чому.

Завдання 2. Чорне і біле крісло.

Мета: формування більш адекватної самооцінки; самопізнання учасників; корекція особистих недоліків.

Узяти два крісла, одне з них накрити білою тканиною, а інше - чорною. Запропонувати одному з учасників зайняти біле крісло, всі інші члени групи по черзі сідають у чорне крісло і говорять учаснику, який зайняв біле крісло, про (C) Ternovyk Nataliia, Slavina Nataliia

DOI (article): https://doi.org/10.32626/2227-6246.2020-48.272-292 http://journals.uran.ua/index.php/2227-6246 
DOI: https://doi.org/10.32626/2227-6246.2020-48 2020. ВИПУСК 48

його недоліки, які, на їхню думку, заважають йому в спілкуванні.

Цю процедуру проводять із тими учасниками групи, у яких спостерігається явно неадекватна самооцінка. Членам групи із завищеною самооцінкою ведучий пропонує зайняти біле крісло, а із заниженою - чорне.

\section{Завдання 3. На вашу думку...}

Мета: фіксація уваги учасників на своїх особистісних якостях; корекція сприйняття себе.

Учасники діляться на однакові підгрупи. Кожна підгрупа утворює концентричне коло. Члени групи, які стоять у внутрішньому колі, повертаються обличчям до учасників, які стоять у зовнішньому колі, й стають один навпроти одного. Потім член кожної пари внутрішнього кола починає тихо говорити партнеру, як він його сприймає, які почуття він викликає, які особистісні якості впливають на групу. За сигналом ведучого внутрішне коло зміщується вправо на одного учасника. Перша частина процедури закінчується, коли учасники пройдуть по колу, на висхідну позицію. У другій частині процедури аналогічно висловлюють свою думку члени групи, які стоять у зовнішньому колі.

\section{Завдання 4. Розминка.}

Mета: зняття напруження і втоми.

Гра «Ходьба». Кожен учасник групи вигадує, що він зображатиме («ходьба над прірвою», «рух проти натовпу» тощо). Потім кожен учасник імітує дію, а інші намагаються відгадати, що саме він зображує.

\section{Завдання на самопізнання.}

Мета: вироблення навику рефлексії.

Спробуйте уважно подивитися на себе і детально описати в щоденнику причини своїх почуттів, переживань, думок, дій від самого початку зустрічі групи до закінчення. Особливо глибоко проаналізуйте ті моменти, коли ви були незгодні з думкою групи та поводилися не до кінця відверто.

(C) Ternovyk Nataliia, Slavina Nataliia DOI (article): https://doi.org/10.32626/2227-6246.2020-48.272-292 
DOI: https://doi.org/10.32626/2227-6246.2020-48

2020. випУСК 48

Наприкінці заняття кожен учасник оцінює за десятибальною шкалою своє включення в роботу групи.

ЗАНЯТТЯ 4. ТЕМА: ОБРАЗ «Я» (14 годин)

Mета: сприяння осмисленню, переживанню власного «Я»; пробудження потреби в самовдосконаленні шляхом створення ситуацій нового бачення себе.

Орієнтовний зліст заняття

1. Рефлексія щодо минулого заняття.

Які стани ви переживали в період між заняттями? Який настрій переважав? Чи був стан піднесення, спокою відразу після заняття? Упродовж якого часу вам удалося його зберегти? Як ви реагували на негативні впливи?

2. Творча розминка «Привіт, я радий тебе бачити...»

Учасники групи звертаються один до одного по черзі. На закінчення фрази: «Привіт, я радий тебе бачити...»- потрібно сказати щось хороше, приємне, але обов'язково від усієї душі, щиро.

Завдання 1. Я в дитинстві.

Мета: актуалізація емоційної пам'яті.

Ведучий пропонує учасникам групи пригадати, яким чином у дитинстві вони усвідомлювали свою індивідуальність. Слід описати ті обставини, які помітно вплинули на розвиток відчуття, що ви - окрема істота. Необхідно відповісти на запитання: «Що сприяло виникненню у вас почуття власної унікальності?»

\section{Інформування}

Ведучий має дати учасникам групи загальні уявлення про образ «Я» особистості. Наше «Я» - це відображення самого себе у свідомості людини. Безумовно, «Я»- це продукт самопізнання, але сприймає й усвідомлює себе людина цілісно, в усіх своїх іпостасях. Існує фізичне «Я»- моє тіло, моя зовнішність, мій фізичний стан. Емоційне «Я» - мої почуття та переживання, настрої. Інтелектуальне і розумове «Я»- світ моїх думок. Нарешті, людина сприймає себе як істоту соціальну, включену в систему стосунків з іншими (C) Ternovyk Nataliia, Slavina Nataliia

DOI (article): https://doi.org/10.32626/2227-6246.2020-48.272-292 
людьми, у свою професійну діяльність, яка має певні цінності, інтереси, установки. Це - соціальне «Я».

Отже, наше «Я» можна вважати результатом складної інтеграції в єдине ціле різних психічних функцій і властивостей людини.

Тепер спробуємо розібратися у своєму індивідуальному «Я» й осмислити, яку роль відіграє образ «Я» в самосвідомості та самовдосконаленні людини. Оскільки «Я»- це відображення самого себе, відповідно, у кожного формується свій образ «Я», або, як називають це психологи, «Я-концепція». «Я-концепція»- сукупність усіх уявлень індивіда про себе, настановлень, спрямованих на себе: «Хто я?»

\section{Завдання 2. Хто я?}

Мета: вироблення вмінь аналізувати свою «Я-концепцію» .

Напишіть у стовпчик цифри від 1 до 20 і 20 разів дайте відповідь на запитання «Хто я?»; використовуйте для опису себе характеристики, риси, почуття й інтереси, починаючи кожне речення із займенника «Я - ...». По закінченню роботи кожен може прочитати свій перелік решті групи та відрефлексувати ті відчуття, почуття, емоції, думки, що виникли у процесі виконання цього завдання.

Після цього учасники утворюють групи з 2-3 осіб і зачитують один одному власні самоописи, одночасно заповнюючи запропоновану нижче схему. Це завдання дає змогу виявити особливості індивідуального самосприйняття, осмислити, наскільки цілісним є образ власного «Я».

«Я» ТІЛЕСНЕ

«Я» РОЗУМОВЕ

\section{Завдання 3. Хто моє «Я»?}

«Я» ЕМОЦІЙНЕ

«Я» СОЦІАЛЬНЕ

Meта: розвиток здатності до заглибленого самопізнання (з використанням фонової музики).

Заплющте очі, повністю розслабтеся, відключіться від усього зовнішнього та повністю зануртеся в себе, відчуйте своє тіло, свій настрій. Подумки повторюйте: «Перед моєю

(C) Ternovyk Nataliia, Slavina Nataliia DOI (article): https://doi.org/10.32626/2227-6246.2020-48.272-292 
DOI: https://doi.org/10.32626/2227-6246.2020-48

2020. випуск 48

внутрішньою уявою з'являється образ. Образ стає все чіткішим. Образ ясно стоїть переді мною. Образ показує мені, хто є я».

Рерлексія

Чи змогли ви викликати образ? Які відчуття, почуття ви при цьому переживали? Що перешкоджало вам зробити цей образ чіткішим? Які ваші враження? Що нового ви відкрили для себе?

\section{Завдання 4. Шукаємо секрет.}

Мета: вироблення здатності до аналізу глибинних характеристик особистості.

Спробуйте віднайти в собі приховані можливості таким чином. Уявіть, що безглуздий учений створив робота, який являє собою вашу точну копію. Ваш двійник ідентичний вам у всіх деталях. Але оскільки він - знаряддя зла, ви не хотіли б, щоб люди приймали його за вас.

Що є у вас такого, що неможливо продублювати? Як люди, які добре вас знають, могли б виявити підміну?

Якщо є хтось, хто знає ваш секрет, чи міг би він скористатися цим для того, щоб ідентифікувати вас?

Ви відкрили всі секрети, проте робот спромігся відтворити все в точності. Який найважливіший секрет ви відкриєте в останню чергу, щоб і самому переконатися, що ви - це саме ви, а не ваша копія?

\section{Запитання для обговорення}

Із чого складаються ваші уявлення про самих себе?

Яку роль відіграє самооцінка в формуванні образу «Я»?

Чому образ «Я» не завжди відповідає нашій істинній сутності?

Які почуття у вас виникали при виконанні вправи?

Завдання на самопізнання.

1. Напишіть собі листа. Спробуйте в ньому дати ваше реальне бачення себе. Будьте максимально відверті. Опишіть усе, що вас хвилює, тішить, що заважає в своєму самовираженні. Нехай це буде лист-звернення до самого себе.

(C) Ternovyk Nataliia, Slavina Nataliia

DOI (article): https://doi.org/10.32626/2227-6246.2020-48.272-292 
Можете ваше звернення записати на магнітофон. Услухайтеся в себе! Що містить ваше послання - тривогу, надію, радість? Чи немає у ваших повідомленнях суперечностей? Візьміть за правило робити це щоразу, коли вам важко, коли відчуваєте необхідність виявити свої почуття, краще зрозуміти себе, свої мотиви.

2. Ознайомтесь із моделлю саморозкриття «Вікно Джогарі» (Рудестам, 1990: 74-75).

\section{Висновки}

Отже, для цілеспрямованого впливу на розвиток підлітка у пізнавальній діяльності працівники освіти повинні чітко уявити образ суб'єктності, який i відображається в певних аспектах активності, таких як: обумовленість психічного образу минулим досвідом, потребами, установками, емоціями, цілями і мотивами, що визначають керованість і вибірковість діяльності. Становлення суб'єкта передбачає виникнення процесів розвитку та надання пріоритету цілям, проблемам і виборам щодо розв'язання та формування задач і реалізацій рішень. Так, суб'єктність має суто соціокультурну природу, оскільки кінцева причина дій індивіда завжди охарактеризована у часі, просторі, значенні та серед прямих і непрямих учасників активності.

У наступних наших публікаціях ми продовжуватимемо описувати вправи з розробленої нами тренінгової програми «Розвиток суб’єктності особистості в підлітковому віці».

\section{Література}

Абульханова-Славская К. А. О субъекте психической деятельности. Москва : Наука, 1993. 287 с.

Брушлинский А. В. Проблемы психологии субъекта. Москва : Институт психологии РАН, 1994. 109 с.

Максименко С., Ткач Б., Литвинчук Л., Онуфрієва Л. Нейропсихолінгвістичне дослідження політичних гасел із зовнішньої реклами. Psycholinguistics. Психолінгвістика. Психолингвистика.

(C) Ternovyk Nataliia, Slavina Nataliia DOI (article): https://doi.org/10.32626/2227-6246.2020-48.272-292 
2019. № 26 (1). C. 246-264. URL : https://psycholing-journal.com/ index.php/journal/article/view/715.

Михальчук Н. О. Діалогічна взаємодія школярів з іншомовним текстом в детермінації становлення їх суб'єктності. Оновлення злісту, форл та методів навчання і виховання в закладах освіти: Зб. наук. праць «Наукові записки РДГУ». Рівне, 2008. Вип. 41. C. 127-133.

Рудестам Н. Групповая психотерапия. Москва, 1990. С. 74-75.

Татенко В. О. Суб’єкт психічної активності: природа, функції, розвиток. Психологія суб’єктної активності особистості. Київ : Інститут психології АПН України, 1993. С. 91-93.

Титов В. М. Методологічні проблеми взаємовідношення суб'єкта і діяльності. Актуальні проблели психологї: традищї і сучасність. Матеріали конферениї. Київ, 1993. Т. 3. С. 142-149.

Harre, R. (1983). Personal being. Oxford : Blackwell. 56 p.

\section{References}

Abulkhanova-Slavskaia, K. A. (1993). O subiekte psikhicheskoi deiatelnosti [Issue about the subject of mental activity]. Moskva : Nauka [in Russian].

Brushlinskii, A. V. (1994). Problemy psikhologii subiekta [Problems of the Subject's Psychology]. Moskva : Institut psikhologii RAN [in Russian].

Maksymenko, S., Tkach, B., Lytvynchuk, L., \& Onufriieva, L. (2019). Neiropsykholinhvistychne doslidzhennia politychnykh hasel iz zovnishnoi reklamy [A neuropsycholinguistic research of political slogans from outdoor advertising]. Psycholinguistics. Psykholinhvistyka. Psikholingvistika - Psycholinguistics. Psycholinguistics. Psycholinguistics, 26 (1), 246-264. Retrieved from https://psycholing-journal.com/ index.php/journal/article/view/715 [in Ukrainian].

Mykhalchuck, N. O. (2008). Dialohichna vzaiemodiia shkoliariv z inshomovnym tekstom $\mathrm{v}$ determinatsii stanovlennia yikh subiektnosti [Dialogical interaction of pupils with texts written in foreign language in the determination of schoolchildren's subjectivity]. Onovlennia zmistu, form ta metodiv navchannia $i$ vykhovannia $v$ zakladakh osvity: Zb. nauk. prats "Naukovi zapysky RDHU» - Updating the content, forms and methods of education and upbringing at the educational establishments: Collection of scientific articles «Scientific Notes of RSGU», 41, 127-133. Rivne [in Ukrainian].

Rudestam, N. (1990). Gruppovaia psikhoterapiia [Group Psychotherapy]. Moskva [in Russian].

C Ternovyk Nataliia, Slavina Nataliia

DOI (article): https://doi.org/10.32626/2227-6246.2020-48.272-292 http://journals.uran.ua/index.php/2227-6246 
Tatenko, V. O. (1993). Subiekt psykhichnoi aktyvnosti: pryroda, funktsii, rozvytok [The subject of mental activity: nature, functions, development]. Psykholohiia subiektnoi aktyvnosti osobystosti - Psychology of subjective activity of the personality, (pp. 91-93). Kyiv : Instytut psykhologii APN Ukrainy [in Ukrainian].

Tytov, V. M. (1993). Metodolohichni problemy vzaiemovidnoshennia subiekta i diialnosti [Methodological problems of the relationship between the subject and the activity]. Aktualni problemy psykholohii: tradytsii $i$ suchasnist - Actual problems of psychology: traditions and modern life. Proceedings of the conference, 3, 142-149. Kyiv [in Ukrainian].

Harre, R. (1983). Personal being. Oxford : Blackwell.

Терновик Наталія, Славіна Наталія. Психологічний тренінг розвитку суб'єктності особистості в підлітковому віці

\section{АНОТАЦІЯ}

Мета нашого дослідження - розробити цілісну тренінгову програму розвитку суб'єктності особистості в шкільному віці.

Для розв'язання поставлених у роботі завдань використано такі теоретичні методи дослідження: категоріальний, структурно-функціональний, аналіз, систематизація, моделювання, узагальнення.

Результати дослідження. Зазначено, що категорія "суб'єкт» як якісна характеристика активності людини зумовлює місце і роль людини у світі, здатність до діяльності, самодіяльності, самовизначення та розвитку. В психології під суб'єктом розуміється людина, яка є джерелом цілеспрямованої (а отже, свідомої) активності, підпорядкованої «образу потрібного майбутнього», тобто, - цілі.

Визначено, що ключовим має бути поняття "суб'єкт психічної активності». Зазначено, що людина в цій якості виявляє безпосередню регулятивну дію на власну психіку та посередництвом психіки впливає на оточуючий світ, а зрілий суб'єкт здатен до усвідомлення своєї су-

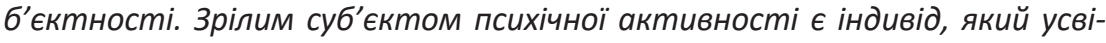
домлює себе носієм і творцем власної психіки, розвиток якої, захист, відновлення та корекцію (у разі потреби) свідомо покладає собі за мету й цілеспрямовано здійснює. Отож, зрілий суб'єкт психічної активності досягатиме рівня суб'єкта психічної діяльності; тобто, свідома регуляція, а також і рефлексія як ії складова, є тим критерієм, який розрізняє ці два

(C) Ternovyk Nataliia, Slavina Nataliia DOI (article): https://doi.org/10.32626/2227-6246.2020-48.272-292 
DOI: https://doi.org/10.32626/2227-6246.2020-48 2020. ВипУск 48

рівні суб'єктності. Наголошено, що суб'єктом психічної активності індивід може мислитися у тому випадку, якщо об'єктом для нього виступає його власна психіка у ії функціонуванні й розвитку. Доведено, що суб'єкт виникає тоді, коли відбувається усвідомлення об'єкта. Підкреслено, що усвідомити об'єкт без рефлексії неможливо, отже, суб'єкт без рефллексії не існує.

Розроблено вправи для тренінгової програми розвитку суб'єктності особистості в підлітковому віці.

Висновок. Доведено, що для цілеспрямованого впливу на розвиток підлітка у пізнавальній діяльності працівники освіти повинні чітко уявити образ суб'єктності, який і відображається в певних аспектах активності, таких як: обумовленість психічного образу минулим досвідом, потребами, установками, емоціями, цілями і мотивами, що визначають керованість і вибірковість діяльності. Становлення суб'єкта передбачає виникнення процесів розвитку та надання пріоритету цілям, проблемам і виборам щодо розв'язання й формування задач і реалізацій рішень. Так, суб'єктність має суто сочіокультурну природу, оскільки кінцева причина дій індивіда завжди охарактеризована у часі, просторі, значенні та серед прямих і непрямих учасників активності.

Ключові слова: суб'єкт, суб'єктність, суб'єкт психічної активності, пізнавальна діяльність, суб'єкт психічної діяльності, тренінгова програма розвитку суб'єктності особистості.

\section{Терновик Наталия, Славина Наталия. Психологический тренинг разви- тия субъектности личности в подростковом возрасте}

\section{АННОТАЦИЯ}

Цель нашего исследования - разработать целостную тренинговую программу развития субъектности личности в школьном возрасте.

Для решения поставленных в работе задач использовались следующие теоретические методы исследования: категориальный, структурно-функциональный анализ, систематизация, моделирование, обобщение.

Результаты исследования. Отмечено, что категория "субъект" как качественная характеристика активности человека предопределяет место и роль человека в мире, способность к деятельности, самодеятельности, самоопределению и развитию. В психологии под «субъек(C) Ternovyk Nataliia, Slavina Nataliia

DOI (article): https://doi.org/10.32626/2227-6246.2020-48.272-292 http://journals.uran.ua/index.php/2227-6246 
DOI: https://doi.org/10.32626/2227-6246.2020-48 2020. випуск 48

том» понимается личность, которая является источником целенаправленной ( $а$, следовательно, - сознательной) активности, подчиненной "образу ожидаемого будущего», то есть - цели этого будущего.

Определено, что ключевым в парадигме нашего исследования должно быть понятие «субъект психической активности». Отмечено, что человек в этом качестве обнаруживает непосредственное регулятивное действие на собственную психику, и посредством психики влияет на окружающий мир, а зрелый субъект способен к осознанию своей субъектности. Зрелым субъектом психической активности является индивид, осознающий себя носителем и творцом собственной психики, развитие которого, защиту, восстановление и коррекцию (в случае необходимости) сознательно возлагает на себя и целенаправленно осуществляет. Итак, зрелый субъект психической активности будет достигать уровня субъекта психической деятельности; то есть, сознательная регуляция, а также и рефлексия как ее составляющая, являются теми критериями, которые различают эти два уровня субъектности. Отмечено, что субъектом психической активности индивид может быть в том случае, если объектом для него выступает его собственная психика в ее функционировании и развитии. Доказано, что субъект возникает тогда, когда происходит осознание объекта. Подчеркнуто, что осознать объект без рефлексии невозможно, следовательно, субъект без рефлексии не существует.

Разработаны упражнения для тренинговой программы по развитию субъектности личности в подростковом возрасте.

Вывод. Доказано, что для целенаправленного влияния на развитие личности в познавательной деятельности учителя должны четко эксплицировать образ субъектности, который и отражается в определенных аспектах активности, таких как: обусловленность психического образа прошлым опытом, потребностями, установками, эмоциями, иелями и мотивами, которые, в свою очередь, определяют степень управляемости и избирательности деятельности. Становление субъекта предполагает возникновение прочессов развития и актуализирование приоритетных целей, формирование задач, проблем и выбора их решения. Таким образом, субъектность имеет сугубо социокультурную природу, поскольку конечная причина действий индивида всегда четко задается определенными характеристиками во времени, пространстве, значениях, а также среди прямых и косвенных участников активности.

(C) Ternovyk Nataliia, Slavina Nataliia DOI (article): https://doi.org/10.32626/2227-6246.2020-48.272-292 
ISSN 2227-6246 (Print)

DOI: https://doi.org/10.32626/2227-6246.2020-48 2020. ВиПУСК 48

Ключевые слова: субъект, субъектность, субъект психической активности, познавательная деятельность, субъект психической деятельности, тренинговая программа развития субъектности личности.

Original manuscript received January 30, 2020 Revised manuscript accepted March 10, 2020

(C) Ternovyk Nataliia, Slavina Nataliia

DOI (article): https://doi.org/10.32626/2227-6246.2020-48.272-292 http://journals.uran.ua/index.php/2227-6246 